\title{
MATERIAL MANAGEMENT PRACTICES FOR CONSTRUCTION WASTE REDUCTION
}

\author{
LILLIANA ABARCA-GUERRERO ${ }^{1}$ \& ANA GRETTEL LEANDRO-HERNANDEZ ${ }^{2}$ \\ ${ }^{1}$ Chemistry School, Instituto Tecnológico de Costa Rica, Costa Rica \\ ${ }^{2}$ Construction Engineering School, Instituto Tecnológico de Costa Rica, Costa Rica
}

\begin{abstract}
The construction sector plays a key role in shaping and developing the built environment creating wealth and development for the countries. At the same time the sector is producing negative impacts due to the vast quantities of natural resources required and the high amounts of waste produced. Costa Rica is a country in Central America that has a construction sector contributing in 2016 a $4.4 \%$ of its GDP. In the country, several studies have been done in order to determine waste quantities but not the composition of the construction residues. Additionally, causes of waste generation have been reported and grouped in the following categories: design, execution, material management, residuals and other activities. This paper presents the results of a research that has been done with the objective to determine the types of hazardous and non-hazardous waste that are produced during the procurement of an edifice as well as the best general practices used by innovative construction companies to reduce the amount of waste produced.
\end{abstract}

Keywords: construction waste materials, hazardous waste, best practices, construction waste reduction.

\section{INTRODUCTION}

The construction industry plays an important role in economic growth and socio-economic development. Any piece of infrastructure or real estate erected around us is undertaken by segments under this industry. Within this industry, the performance of the projects are mostly based on labour costs which not consider sustainability aspects and the negative impact on the environment [1]. This industry is perceived as a major contributor to environmental degradation. It consumes large quantities of natural resources, while producing large volumes of waste [2]. It is reported in literature amounts of residues of this activity by weight in final disposal sites as high as 57\% in Japan [3], or an average for the world between $13 \%$ and $29 \%$ [4].

Construction waste is becoming a serious environmental problem in many large cities in the developing world arising concerns in the population at the local context and challenging the industry to become more environmentally friendly and promote sustainability [5], [6].

Costa Rica is a developing country in Central America in which the sector provided approximately $4.4 \%$ to the GDP during 2016 [7]. This sector was responsible for the construction of $10388384 \mathrm{~m}^{2}$, being housing and commercial construction the highest percentage, 65\% [8]. Different studies have reported construction waste generation with values such as $300-700 \mathrm{~kg} / \mathrm{m}^{2}$ [9], $11-25 \mathrm{~kg} / \mathrm{m}^{2}$ [10], $115 \mathrm{~kg} / \mathrm{m}^{2}$ [11] and $24,1 \mathrm{~kg} / \mathrm{m}^{2}$ [12]. It has also been studied the reasons for it which have been classified in the following categories: design, execution, material management, residuals and other activities [13].

It has been mentioned by different researchers that developing countries are characterized by poor information system, inadequate and inaccurate data, especially those related to the construction activity [14]. Additionally, searching in literature for construction waste materials and the best practices for construction material management as an element for waste reduction, it was proven that most of the information are related to developed countries. 
In an effort to bridge some of these gaps, the objective of this article is to inform the findings on a study performed in Costa Rica with the support of the Costa Rican Construction Chamber. The objective is to present the hazardous and non-hazardous waste produced as well as a view of the general best practices employed by construction companies to reduce the generation of waste.

\section{RESEARCH METHODOLOGY}

\subsection{Literature review}

The literature review provided the items tapping the theoretical constructs for the research. Several authors have reported causes of construction waste generation [15]-[17], as well as good practices to reduce them [18]-[20], among others.

\subsection{Data collection}

It utilized a mixed method approach, in which a survey instrument was applied to small, medium and big construction companies, structured interviews were held, on-site visits and a panel experts' discussion validated the collected information.

\subsection{Survey instrument}

Two survey instruments were constructed based on the information gathered during the literature study. Survey one contained questions related to general information about the company and the types of waste produced which were divided in two groups: nonhazardous and hazardous waste. The data was collected vis-à-vis in 30 small, 15 medium and 7 big construction companies. Descriptive statistics was used to analyse the variables including central tendency and frequencies. Survey two had the Architects and Designers as a target group. It was placed on the website of the Architects Federation. It included questions associated to causes of waste generation during the design phase and good practices that can be applied to prevent its generation.

Prior to data collection, the survey instruments were pre-tested for ease of understanding and content validity. Based on the feedback received, the instruments were modified to enhance clarity and appropriateness of the measures purporting to tap the constructs.

For survey two, efforts were made to ensure high quality responses from respondents. These included: a personalized cover letter; a confidentiality statement to assure strict confidence on the information provided and telephone follow-ups of all non-respondents after two weeks of the survey being on-line.

\subsection{Interview data}

Structured interviews were carried out to key persons from 5 innovative big construction firms. They were intended for enriching the data of the surveys and for the discussion of good practices utilized in those companies for construction waste reduction.

\subsection{On-site visits}

Construction projects were visited to determine the type of waste being produced, the possible causes for its generation and the good practices applied for waste reduction. 


\subsection{Panel experts' discussion}

A panel of experts' discussion took place with the objective to explore the meanings of the survey results, to analyse the participants' views on the presented topics and to collect a wider insight into different opinions [21].

The group was composed of 20 professionals from the construction industry, including companies that participated in the survey, representatives of Federation of Engineers and Architects, academic sector, Costa Rican Construction Chamber and Non-Governmental Organisations working in sustainable construction. It was conducted over approximately two hours, beginning with a 30-minute presentation of the research's results followed by an analysis of the good practices which were divided in six groups. Each of the group members was free to express his/her minds openly.

\section{RESULTS AND DISCUSSION}

\subsection{Responding firms}

A total of 52 construction companies answered the questionnaire. The sample was composed of 30 micro and small enterprises with less than 10 workers, 15 medium with more than 10 and less than 100 workers and 7 big with more than 100 workers.

\subsection{Types of waste produced at the construction site}

The study revealed that the companies produced in general non-hazardous and hazardous waste. They are the following materials:

$\begin{array}{ll} & \text { NON-HAZARDOUS } \\ \text { - } & \text { Metal piping pieces } \\ \text { - } & \text { Cement paper-plastic bags } \\ \text { - } & \text { Electric wire } \\ \text { - } & \text { Ceramic pieces } \\ \text { - Cooper from piping } \\ \text { - Concrete } \\ \text { - Masonry (concrete with metal) } \\ \text { - Styrofoam } \\ \text { - Malfunctioning equipment } \\ \text { - Iron pieces } \\ \text { - Broken bricks } \\ \text { - Corrugated roof sheet pieces } \\ \text { - Brass } \\ \text { - Bronze (locks) } \\ \text { - } \text { Wood } \\ \text { - Insulation material } \\ \text { - Soil materials } \\ \text { - Packaging paper materials } \\ \text { - } \quad \text { Melamine }\end{array}$

\section{HAZARDOUS}

- Acids

- Solvents and detergents

- Concrete additives

- Concrete release

- Oil containers

- Lubricants

- Metal paint containers

- Plastic paint containers

- Chemical treated wood

- Paint

- Asbestos

- Lubricants

- Fibre glass

- Welding materials

- Chemical treated wood

- Silicon and other sealing materials

- Contaminated soil

- Textiles with solvents

- Paint brushes

- Lighting systems 
- Light walls materials

- Stones

- Marble

- Granite

- Polyvinyl chloride (PVC)

- Gypsum

- Handle mortar

- Plaster

- Sets

- Clothing

- Glass

\subsection{Best practices for construction waste reduction}

The best practices are separated by design, material management, procurement management, execution stages, residuals and others.

\subsubsection{Design}

Good practices in the design stage are related to:

- Using modular coordination with modular products and construction systems

- $\quad$ Producing a 3D model, detailed and simple workshop drawings

- Using prefabricated structures, units and products

- Coordinating among the different professionals, technicians and clients involved in the project

- Designers being aware of available material, products and dimensions in the market as well as waste reduction processes

- Designers considering reuse, recycling and deconstruction while designing

- Planning the quantity and quality of materials, the generation of waste and its possible treatment, the construction techniques, the human resources and machinery needed

- Following up during the construction on the instructions of designer, structural, electric and topographer engineers

- Clients being aware about environmental friendly materials, resistant and nontoxic elements, the impact of waste generation and the benefits to reduce them and the money savings

3.3.2 Material management

Good practices in the material management stage are correlated to:

- Controlling and examining materials at their arrival and in the storage room, including expiration date

- Packaging and care of materials during transportation, in the on-site storage and while construction goes on

- Training to employees on the use and management of materials

- Encouraging reuse and collection for recycling of building materials

- Developing environmental culture of the company 
- Establishing clear communication mechanisms between the workers and the foreman on materials management

- Creating incentive policies to promote environmental culture for the employees

- Sub-contractors following good practices for material management otherwise fines applied

\subsubsection{Procurement management}

Good practices in the procurement management stage are connected to:

- Making a good procurement planning for materials

- Suppliers providing flexibility to order small quantities

- Storing remaining materials for future projects

- Ordering materials with quality certification

- Ensuring that the materials to be ordered have the purchase approvals

- Buying locally sourced materials (aggregates, ceramic elements and others)

\subsubsection{Execution}

Good practices for this stage are associated to:

- Good planning and material management strategies during the planning and design stages

- Establishing control procedures for: budget, material specifications and their quality, material and waste management, collection for recycling, purchase, change of orders and acceptance of materials

- Choosing the right technology, equipment and tools for the processes, their maintenance before, during and after finishing the tasks

- Labour training plans for the use of materials, tools and equipment, material and waste management

- Training employees on process technologies, safety and hygiene and the importance of the environment

- Acknowledging the use of good practices by economic incentives, encouraging the employees in providing ideas and suggestion for an improved execution

- Considering the site lay-out that bear in mind temporarily spaces and structures that facilitate material and waste management

\subsubsection{Residuals}

Good practices considered in residuals are related to:

- Protecting and using removed soil for gardening and green areas

- Controlling and registering the amount of waste generated and its disposal

- $\quad$ Sorting and separating the waste when generated to prevent mixing

- Reusing surplus materials (e.g. formwork, bricks, ceramics) in the same or in other projects

- Keeping clean working areas

- Appling incentives to contractors that reduce or collect waste for recycling as well as penalties for incorrect waste management practices

- Agreeing with supplier's strategies for preventing materials deterioration 
3.3.6 Others

Good practices for other activities are correlated to:

- Developing strategies for storage and materials protection

- Developing a waste management plan that includes resources needed and materials that can be reused or recycled

- Keeping records of waste generation and causes

- Informing the staff about their responsibilities regarding waste handling

- Creating mechanisms to control waste being disposed, frequency and final disposal

- Identifying potential buyers/sellers of used or recycled materials, recycling facilities available near the project and discuss with them the possibilities and requirements for their services

- Providing training programs to help customers and stakeholders to appreciate the benefits waste reduction

\section{CONCLUSIONS}

1. The study demonstrated that most of the construction sites produce hazardous and nonhazardous waste. The reduction of those materials can lead to important savings in purchasing, treatment and disposal costs.

2. Many factors influence waste generation however it was proved that reduction can be achieved by establishing good practices.

3. The research demonstrated that construction waste can be generated during any phase of the life cycle of project. The application of best practices can reduce it.

4. The general best practices for material management for waste reduction presented in this paper can be applied before and during the construction processes. It is meant for contractors that either develop new projects as well as for repair or refurbishing ones.

5. The use of the best practices presented promote reduction of construction waste sent to disposal sites, thus demonstrating a contribution to sustainable development and reducing project costs.

6. The best practices can be applied without big changes in the construction processes.

7. Project stakeholders must work together and understand the benefits of implementing and follow good practices on waste management to assure waste reduction.

\section{ACKNOWLEDGMENTS}

We thank the Costa Rica Institute of Technology, Eindhoven University of Technology in the Netherlands, the Costa Rican Construction Chamber and construction companies for the technical support and the Deutche Gesellschaft für Internationale Zusammenarbeit (GIZ) for the financial contribution.

\section{REFERENCES}

[1] Ofori, G., Contemporary issues in construction in developing countries. SPON Press: New York, 2012.

[2] Leandro-Hernández, A.G., Manejo de desechos de la construcción. Tecnología en Marcha, 21(4), pp. 60-63, 2008.

[3] Kennedy, C., Cuddihy, J. \& Engel Yan, J., The changing metabolism of cities. Journal of Industrial Ecology, 11(2), pp. 43-59, 2008. 
[4] Bossink, B.A.G. \& Brouwers, H.J.H., Construction waste: quantification and source evaluation. Journal of Construction Engineering and Management, 122(1), pp. 55-60, 1996.

[5] Abarca-Guerrero, L., Construction waste generation model for developing countries, $\mathrm{PhD}$ thesis, Eindhoven University of Technology, The Netherlands, 2014.

[6] Leandro-Hernández, A.G., Construction Waste Management. Proceedings for the third International Conference on construction on developing countries, 2012.

[7] Cámara Costarricense de la Construcción (CCC). Online www.construccion.co.cr. Accessed on: 17 Jun. 2016.

[8] Colegio Federado de Ingenieros y Arquitectos (CFIA). Online, www.cfia.or.cr/descargas2016/estadisticas/reporteAnual2016.pdf. Accessed on: 15 Jun. 2016.

[9] Ramírez, M., Impacto físico y financiero de la generación de desechos sólidos en la construcción de dos proyectos hotelero, Lic thesis, Universidad de Costa Rica, 1995.

[10] Villalobos, A., Estudio de generación de desechos en la construcción de viviendas de mampostería, Lic thesis, Universidad de Costa Rica, 1995.

[11] Leandro-Hernández, A.G., Administración y manejo de los desechos en proyectos de construcción. Etapa 1: evaluación y monitoreo, Research project, Instituto Tecnológico de Costa Rica, 2005.

[12] Abarca-Guerrero, L., Sustainable construction in Costa Rica: Towards a strategic approach to construction material management for waste reduction (Keynote speaker). Costa Rican Congress of Civil Engineers, Costa Rica, 2008.

[13] Abarca-Guerrero, L. \& Leandro-Hernández, A.G., Guía Manejo eficiente de materiales de construcción. Instituto Tecnológico de Costa Rica, Cámara Costarricense de la Construcción, 2016. http://www.construccion.co.cr/descargas/ GUIA_MANEJO_MATERIALES_CONSTRUCCION.pdf.

[14] Yuan, H. \& Shen, L., Trend of the research on construction and demolition waste management. Waste Management Journal, 31(4) pp. 670-679, 2011.

[15] Abarca-Guerrero, L., A construction waste generation model for developing countries. Ph.D thesis, Eindhoven University of Technology, The Netherlands, 2014.

[16] Ekanayake, L.L. \& Ofori, G., Building waste assessment score: design-based tool. Building and Environment, 39(7), pp. 851-861, 2004.

[17] Bossink, B.A.G. \& Brouwers, H.J.H., Construction waste: quantification and source evaluation. Journal of Construction Engineering and Management, 122(1), pp. 55-60, 1996.

[18] Gangolells, M., Casals, M., Forcada, N. \& Macarulla, M., Analysis of the implementation of effective waste management practices in construction projects and sites. Resources, Conservation and Recycling, 93, pp. 99-111, 2014. doi:10.1016/j.resconrec.2014.10.006.

[19] Yates, J. K., Sustainable methods for waste minimisation in construction. Construction Innovation, 13(3), 281-301. doi:10.1108/CI-Nov-2011-0054.

[20] Leandro-Hernández, A.G., Manejo de desechos de la construcción. Tecnología en Marcha, 21(4), pp. 60-63, 2008.

[21] ODI (Oversees Development Institute). Research tools: Focus group discussions Online www.odi.org.uk/publications/5695-focus-group-discussion. Accessed on: 23 Nov. 2016. 